\title{
The changing identity of Anglo Americans in Texas, 1836-1845
}

\section{Andrea Kökény}

Historian William Taylor speaking of Americans in his book, Cavalier and Yankee, stated the following:

„Few things are more characteristic of the eighteen twenties, thirties and forties than the absorption with what was called the national character." His observation is at least equally true for those Americans who became „Texians” during these years. But Anglo-Texan nationalism was a fragile thing. ${ }^{2}$ Its roots can be traced with the appearance of Anglo-Americans in Texas.

Mexico became independent from Spain in 1821, and prospective settlers from the United States began to arrive in Stephen F. Austin's colony by the end of that year. The National Colonization Law of 1824 left the individual states of Mexico with complete control over immigration and the distribution of public lands. The Anglo Americans, who arrived in Texas had to pay only modest fees for generous amounts of land. They became Mexicans in the legal sense of citizenship, bound by the laws of the country, but their collective mentality, culture, and language was American.

Historian Mark E. Nackman stated that during the Mexican period the Anglo Americans who lived in Texas were neither Mexicans nor Americans. ${ }^{3}$ However, I would agree with the argument of another historian James E. Crisp, that they were both. ${ }^{4}$ Carol Lea Clark approached the question in a different way and said that "Anglo-American Texans had a divided rhetorical identity; they were exAmericans, but they were also something else. They were not sure what that something was, but they could define what it was not - Mexican, Indian, or even "ordinary' American." I would argue that they had multiple or shifting identities. Very often they referred to their Anglo-Saxon origins. Coming from the United States, they brought with them the ideas of self-government and republicanism. In order to be accepted by Mexican authorities, however, they had to abide by Mexican rules and regulations. As they manuevered between these two poles, their guiding principle was almost always their personal interest.

When the young Republic of Mexico introduced a generous land policy, Anglo-American emigrants had wanted to make use of the opportunity and left their homes in the United States of America. Many of them had "gone to Texas" to escape their debts or the law, and to seek economic advancement. When Santa Anna led a centralist turn in Mexico in 1835 that endangered the prospects of self-government and economic prosperity for Texas, Anglo Americans revolted against him. After declaring their independence from Mexico, they drafted a constitution and the same day they applied for statehood in the United States. It was only when the US rejected them, that they found themselves in the need of self-definition along new terms. They were not Mexicans any more, but they could not be Americans either, even though in their hearts and their traditions they were. They were Anglo Americans living in Texas, but during the nine years of their independent history they tried to describe and define themselves as a group with a separate national identity, and called themselves "Texians".

We can ask the question that in an age of self-conscious romantic nationalism, what did it mean to be a Texian? If Texas was to be a nation, what kind of nation was it to be? This is what I examined through the close study of a very important primary source of the era, the press. I have analysed the second permanent newspaper printed in Texas, the Telegraph and Texas Register.

The first issue was published in San Felipe de Austin on October 10, 1835, just nine days after the first shot of the Texas Revolution. The newspaper carried detailed information about the situation in

\footnotetext{
${ }^{1}$ William R. TAYLOR, Cavalier and Yankee, The Old South and the American National Character, New York, 1961, 18-19

2 James E. CRISP, Anglo-Texan Attitudes Toward the Mexican, 1821-1845, Ph.D. diss., Yale University, 1976, 197

${ }^{3}$ Mark E. NACKMAN, A Nation within a Nation: The Rise of Texas Nationalism, Port Washington, N.Y., Kennikat Press, 1975, 13

${ }^{4}$ James E. CRISP, Ibidem, chapter ii.

5 Carol Lea CLARK, Imagining Texas, Pre-Revolutionary Texas Newspapers, 1829-1836, El Paso, Texas Western Press, 2002, 14
} 
Texas and tried to be as objective as it could, often presenting different opinions about a question. Its editors and printers were witnesses to the changes throughout the years of the Texas Republic and after. The paper was a faithful mirror of the events, the thoughts, and the attitudes of people. At the same time, it was also an influential molder of public opinion. The Telegraph has become an essential source to the understaning of the early history of American Texas and the changing identity of the people who lived in it. It reflects the most important elements of self-definition. It provides information about the American settlers' motives, expectations and hopes during the transitional period of 1836-1845.

The Telegraph proudly drew parallels between the United States and the Texas struggles for independence. The editorial of September 6, 1836 commemorated the revolutionary battles of the American War of Independence and made a similar list about Texas "during her struggle for independence since the year 1827" remembering the events of the Fredonian Republic, Fort Velasco, Anahuac, Gonzales, etc. The analogy was simple: "as the example set by that country has contributed much towards the raising spirit of Liberty and the adoption of free institutions among the nations of the American Continent and Mexico; so may the political regeneration of this Republic be the means of effecting a most essential vicissitude in the condition of the former empire of Montezuma. It is morally certain that the Anglo-American principles and polity will in the course of time extend across the Rocky Mountains to the Pacific, carrying along with them all the consequent improvements and changes, from the vis inertiae to a restless desire of aggrandizement and amelioration of circumstances."

The newspaper reflected the American ideology of westward movement and Manifest Destiny. ${ }^{6}$ The idea of America's Divine mission was as important an element in formulating the identity of the American settlers as the heroic deeds of the Texas Revolution which were immortalized in patriotic songs and poetry. An editorial published just days after the fall of the Alamo predicted that "the spark of immortality which animated your forms, shall brighten into a flame, and Texas, the whole world shall hail ye like demi-gods of old, as founders of new actions, and as patterns for imitation.",

The Hymn of the Alamo published in the Telegraph in the fall of 1836, emphasized the nobility of death in a worthy cause.

\footnotetext{
"Here, on this new Thermopylae,

Our monument shall tower on high, And 'Alamo' hereafter be

In bloodier fields the battle cry."

Thus Travis from the rampart cried,

And when his warriors saw the foe,

Like angry billows more below,

Each dauntless heart at once replied,

"Welcome to the Spartan's death -

'Tis no despairing strife -

We fall, we die, but our expiring breath

Is freedom's breath of life."
}

Another example of patriotic feelings, the Texian Hymn of Liberty portrayed the fight between Texas and Mexico as the struggle of good and evil, light and darkness, liberty and despotism, and freedom and oppression. This poem, which glorified the heroism of triumphant Texians, was written by Sephen C. Parmenter and published in the Telegraph in the summer of 1838.

Arise, arise brave Texians, awake to Liberty,

To Mexican oppressors no longer bend the knee,

But hasten to the combat, with freedom's flag unfurled,

That the glorious deeds of Texas shall echo thro' the world;

\footnotetext{
${ }^{6}$ For analysis of the idea of Anglo-American mission and manifest destiny see Frederick MERK, Manifest destiny and mission in American history, a reinterpretation with the collaboration of Lois Bannister Merk, with a new foreword by John Mack Faragher, Cambridge, Massachusetts, Harvard University Press, 1995.

${ }^{7}$ Telegraph and Texas Register, March 24, 1836.

${ }^{8}$ Telegraph and Texas Register, October 4, 1836.
} 
For we are determined to die or be free,

And Texas triumphant our watch word shall be. ${ }^{9}$

Examining and building on the past is always an important element of nationionalism and national identity. In the Telegraph and Texas Register we can find references not only to the legends and myths of European civilization - like the presentation of Texans as noble Greeks -, but also manifestations of the conscious efforts of Texan leaders to create and record their own past. Following the death of Stephen F. Austin on December 27, 1836, the Telegraph carried Lamar's proposal for publishing a biography of Stephen F. Austin. He asked the readers for authentic information to "contribute to a work intended to preserve from oblivion the name of the father of our country, and to transmit to posterity an impartial history of his life, his sufferings and his virtues."10

The Telegraph laid great emphasis on publicizing and justifying the cause of the Texas Revolution. For example, it published the Treaty Between the United States and the French Republic of April 30, 1803 (i.e. the document of the Louisiana Purchase) to prove that Texas had been part of Louisiana. ${ }^{11}$ During the spring of 1837 the issues carried "documents relative to the political condition of Texas, during the commencement of the war" arguing that "these articles will be useful abroad, in furnishing evidence of the events which led to the rupture with Mexico, and of the true grounds upon which we rested the justice of our cause; and at home in displaying to our children, some of the brightest examples of republican virtue, which may stimulate them to imitate the noble achievements of their fathers ..."12 It also published a translation of the laws, orders and contracts of colonization, from 1821, up to 1829; in virtue of which Col. Stephen F. Austin introduced and settled foreign emigrants in Texas. ${ }^{13}$

To ensure the growth and strengthening of the Republic, the government pursued prospective settlers and colonizers, and the Telegraph cooperated in this enterprise by advertising the many advantages of Texas. The promotion of Texas was as important as establishing a good reputation. The editorials often gave accounts of the arrival of new settlers and tried to give guidelines for them. "Large numbers of emigrants are continually arriving from the US. We notice with pleasure that most of them are well supplied with good rifles. We fear however that too small a portion of them are farmers. Those desirous of emigrating should continually bear in mind that Texas is an agricultural country and therefore offers at present but few inducements to any except practical farmers."14

The Telegraph published a letter to the editor about the arrival of a number of "highly respectable ladies to our city" interpreting the event as a positive sign "for the future prosperity of our adopted country."

Every intelligent and virtuous citizen should hail their advent as propitious. It is fraught with the deepest interests, social, moral and political to every community and republic antire. They come from various regions, where country and home, and kindred, all combined to render the changes desireless and the contrast discouraging, but they come, we fondly hope to share with us in the 'land of promise' the cherished privileges of civil rights.

For the relinquishment of kindred endearments, and home's varied ties, we point them to our favored country, where the band of sociability and the prerogatives of affection may again be renewed, and matured in felicity. We point them to our treasures in the mountains; to the congeniality of our climate; to our extended forests, whose virgin soil is inviting the emigrant to her bounties. We point them to our dawning institutions, whose standard was that of another

\footnotetext{
${ }^{9}$ Telegraph and Texas Register, July 28, 1838.

${ }^{10}$ Telegraph and Texas Register, February 3, 1837.

${ }^{11}$ Telegraph and Texas Register, February 21, 1837.

12 Telegraph and Texas Register, March 28, 1837.

13 Among the documents we can find the "Colonization Law of 1823 " as well as the "Official Communication from Don Antonio Martinez, Governor of Texas, to Moses Austin.” Telegraph and Texas Register, April 11, 1837. The Telegraph also published the "Decrees of the Emperor, the Sovereign Congress, the Supreme Executive Power," the "Official Letter from Governor Garcia, to the Commissioner Bastrop, naming the town of San Felipe de Austin," "13 and the "Colonization Law of the State of Coahuila and Texas." Telegraph and Texas Register, May 16, 1837.

${ }^{14}$ Telegraph and Texas Register, December 2, 1837.
} 
land, and whose supporters have descended from the family of 'seventy six.' All these privileges shall be theirs. ${ }^{15}$

The physical environment and the hardships of starting all over in a different land had a strong influence on the immigrants who arrived in Texas. By evoking the image of Texas as a natural garden, the Telegraph aimed at attracting prospective settlers as well as encouraging the ones who had already been there. By linking Texas political values to the generation of the American Revolution, then, the Telegraph suggested continuity for new immigrants from the United States. Emphasizing the similarities of the social environment and the political principles made it easier for the AngloAmerican settlers to identify with each other.

Another important element in the formulation of identity among the Anglo Americans who lived in Texas was their attempt to define themselves in relation to others. In deciding if "we" are like or unlike "them," they often referred to the Hispanic and Indian population in their vicinity.

Historian James E. Crisp pointed out that often there was an association of Mexicans and Indians in the rhetoric of the Anglo-Texans. There were many cases when Indian characteristics were attributed to the Mexican, and vice versa.$^{16}$ As early as 1836, the Telegraph suggested that the Mexicans "behold the prostrated power and destruction of the Indian tribes, and ... tremble for fear that the same destiny is allotted to him. ${ }^{17}$ In the spring of 1840, the Telegraph warned of the inflammable materials "now collected in the western part of our territory, consisting of hostile Indians, renegade slaves, Centralist and Federalist soldiers," that is, Mexicans. ${ }^{18}$

The economic and political backwardness of Mexicans compared to the development of Texas and the democratic principles that guided the Republic, were not the only features that were listed to show the differences between the two peoples. The negative picture of the Mexicans was contrasted with the positive self-image of the Texians and their special mission to progress and spread the democratic institutions and ideas on the American continent. I would agree with James Crisp's argument that "the longer Texas remained an independent nation, the stronger became the impulse to define Texas identity in the racial terms implied by the concept of Anglo-Saxonism." It implied that "the Texans' abilities in the realm of self-government were not merely the result of lessons learned from the American example of revolution and independence, but were qualities which originated in the AngloAmerican people themselves." 19 There were different manifestations of this doctrine in the Telegraph, too. In the summer of 1839 when it was anticipated that Mexico would attempt an invasion of Texas in September, the Telegraph called for action. "We would say, let every citizen be prepared with his horse, rifle and ammunition, so as to be ready at a moment's warning to rally to the rescue." ${ }^{, 20}$ The reasoning reflected the commonly held ideas about the racial differences, which could also justify the idea of mission.

A marked difference exists between the population in the middle and south of Mexico, and those dwelling in the northern provinces - the latter are much more hardy, robust and industrious than the effeminate and besotted nations of the southern latitudes. In physical and moral energy, they approximate the anglo-saxon race; and all that is wanting to fit them for free institutions is education. Among such friends, the Federalists will be able to defend themselves against the government.

The Federalists of the north are strongly inclined to separation, and with the help of Texas, they will no doubt be able to erect a free and independent government."21

The editorials repeated the same ideological and racial argument, but as time went by, staying out of the internal conflicts of Mexico got more emphasis.

\footnotetext{
${ }^{15}$ Telegraph and Texas Register, March 10, 1838.

${ }^{16}$ James E. CRISP, Anglo-Texas Attitudes Towards the Mexican, 113-126

${ }^{17}$ Telegraph and Texas Register, August 23, 1836.

${ }^{18}$ Telegraph and Texas Register, April 29, 1840.

${ }^{19}$ James E. CRISP, Ibidem, 211-213

${ }^{20}$ Telegraph and Texas Register, July 19, 1839.

${ }^{21}$ Telegraph and Texas Register, July 19, 1839.
} 
Several of the northern Mexican states are making formidable preparations to oppose the power of centralism in that portion of Mexico -

Those states have a population of about two million and a half, and compose infinitely the best portion of the Mexican nation. Those northern states have more of the Castilian blood and have mixed less with the Indians than the more southern states. This added to their intercourse with the people of the United States, and their habits of using the rifle, will give them decided advantage over the more southern people of the Mexican republic.... We have no objection to acknowledge their independence so soon as they shall establish a good government, and show to the world their ability to maintain it; but we cannot involve ourselves in their difficulties. ${ }^{22}$

Rumours ... are circulated by rash adventurers, who wish our Government to engage in the political broil between the Federalists and the Centralists. If we are wise we shall keep aloof from both parties. Both are Mexicans; and experience has taught us, that Mexican and AngloAmerican politics never can combine: the two people are separate and distinct, and should remain so. They may form treaties of amity and commerce, but they never can be blended under one government to their mutual advantage; for the very reason that they are NOT EQUAL. ${ }^{23}$

At the end of February, 1842 Mexican troops under General Rafael Vásquez crossed into Texas unopposed and captured San Antonio on March 5. On the one hand, the Telegraph reflected the tensions caused by the danger of Mexican invasion, one the other hand, it expressed the determination of the people of Texas to stand up to the challenge. Public opinion demanded vengeance and put pressure on President Houston to start a counter offensive. It turned against the Mexicans giving voice to imperial ambitions. The young Republic, at the stage of evolving nationalism, wanted to ensure solidarity and patriotism at home to be able to carry out offensive operations and achieve expansion. The editors of the Telegraph, however, being aware of the financial difficulties of the republic and the lack of regular soldiers, warned against invading Mexico.

Texas nationalism developed in the process of nation building as well as the struggle for survival not only politically (trying to preserve independence), but also economically. Texians gradually started to regard themselves as a group having a separate identity. At the same time, they never wholly forgot about their native land. They were in a special situation. Unlike most new nations, they had an alternative to independence: joining the United States. The Telegraph and Texas Register time and again argued for annexation. At the end of 1837, it discussed the history of Texas as "an important preliminary to the due consideration of the subject of annexation" arguing that "Texas seeks to be annexed, first and foremost, because she is a nation of the same blood with the people of the US. The history of this country is her history." ${ }^{24}$ The Telegraph often quoted different US newspapers that discussed the issue. Years passed, Sam Houston withdrew the application for statehood, ${ }^{25}$ but the editor still hoped for a favorable decision. What is more, in the middle of 1840 he presented the measure as if it had become a necessity to the United States. ${ }^{26}$

Soon, however, public opinion appeared to shift. The number of immigrants increased, economic prospects were positive, there was a growing self-sufficiency, and national pride started to rise, too. In the fall of 1843, the Telegraph reported on the secret negotiations relative to the mediation of Great Britain and Mexico, at the same time expected support from the United States, too. ${ }^{27}$ Then an editorial written in December, 1843 carried an argument that showed that Texians were becoming psychologically prepared to carry on by themselves and seek a future of their own:

\footnotetext{
${ }^{22}$ Telegraph and Texas Register, August 28, 1839.

${ }^{23}$ Telegraph and Texas Register, June 24, 1840.

${ }^{24}$ Telegraph and Texas Register, December 6, 1837.

${ }^{25}$ The Texas Congress ratified the decision on January 23, 1839. Rupert N. RICHARDSON, Texas, The Lone Star State, $3^{\text {rd }}$ ed., Englewood Cliffs, N.J., Prentice Hall, 1970, 136

${ }^{26}$ Telegraph and Texas Register, June 10, 1840.

${ }^{27}$ Telegraph and Texas Register, October 11, 1843.
} 
The people of our father-land have become fully convinced that it is time the fruitless war between Mexico and Texas had ceased, and they will cheerfully sustain their President in coercing Mexico, to grant at an early day the unconditional acknowledgement of the independence of Texas. They have noticed year after year pass by until a longer period of war has elapse, than that of the American Revolution, and they find Mexico still incompetent to reconquer her lost province and still withholding peace. They consider therefore that the great principles of humanity and justice that induced a large portion of the civilized world to demand that Britain should grant peace to her revolted colonies, after a fruitless contest of seven years duration to reconquer them, should induce them to step forth and compel Mexico to relinquish a war that is conducted in violation of the first principles of civilization. The question of annexation may fail - but there is no longer a doubt that the independence of Texas will be promptly secured. The very persons who are now strenous in opposing the annexation of Texas to the Union will unite with the friends of President Tyler and aid him in extorting from Mexico the acknowledgement of the independence of Texas. ${ }^{28}$

An informal armistice was finally concluded with Mexico in February, 1844. In the meantime Sam Houston's diplomats and the American government resumed the annexation negotiations, although Texians also explored the possibility of making commercial and political commitments to Great Britain. ${ }^{29}$ The Telegraph reported on the different alternatives quoting exchange papers and commenting on public opinion. The paper's tone was not objective. It expressed the sentiments of its editor, who, like many other Texians, favored annexation. In February, 1844 it carried the 'glorious news':

We have received intelligence from sources of high authority, that the Senate of the US has almost unanimously ratified a treaty for the annexation of Texas to the US. ... This news may seem too good to be true ... Ere another harvest is gathered in Texas, the broad banner of Washington may be unfurled in glory on our western border, and the burnished arms of American troops will be reflected from the sparkling waters of the Nueces. "Westward! The Star of empire takes its way! ${ }^{30}$

The American Senate rejected the annexation treaty in June, 1844, but the Telegraph did not give up on the issue, although it acknowledged that there was a great diversity of opinions relative to the fate of the annexation.

The editorial of March 5, 1845 that commented on the Texian national holiday reflected the weariness of the editor, but at the same time his contentment and optimism, too.

The Ninth Anniversary of our National Independence has brought with it perhaps fewer pleasing recollections than any that preceded it, but still it must be a source of pride for the patriot to trace in the events of the past year renewed evidences that the tide of national prosperity has not been ebbing. ${ }^{31}$

Finally, the 'Joint resolution of the Senate and the House of United States Congress for Annexing Texas to the US' was published on the front page of the April 16th Telegraph and Texas Register. The editorial described the general support and the celebrations that were held all over Texas to express the popular will.

From every section of the Republic we hear but the continued roar of plaudits, as the people assemble in county after county to testify their approbation of the terms for annexation offered by the American government. The thunders of applause resound on every side. The whirlwind of public opinion has swept down all opposition." Commenting on the documents it concluded that "every intelligent and candid reader will, on examining them minutely, admit

\footnotetext{
${ }^{28}$ Telegraph and Texas Register, December 27, 1843.

${ }^{29}$ On Sam Houston planning the annexation of Texas to the United States see Marquis JAMES, The Raven, $A$

Biography of Sam Houston, Chapter XXV, New York City, Blue Ribbon Books, Inc., 1929.

${ }^{30}$ Telegraph and Texas Register, February 14, 1844.

${ }^{31}$ Telegraph and Texas Register, March 5, 1845.
} 
that they grant to the citizens of Texas all the rights, privileges, and immunities enjoyed by the citizens of the United States. ${ }^{32}$

In the following issues there were more reports about the annexation meetings in the different counties. Their general tone expressed relief as well as optimism about the future of Texas.

The farmer deserted his plough - the blacksmith his forge and anvil - the merchant his desk - the lawyer his books - the physician his drugs - the carpenter his square and line, and all repaired to the appointee place to express their joy at the flattering prospects of re-union to the United States, and shout a hearty God speed to annexation.

"The reannexation of Texas to the US, is believed to be promotive of the security, the prosperity, and the happiness of the people, and calculated to advance the mutual welfare of both countries. ${ }^{33}$

A news item from the middle of August, 1845 revealed the real motives behind making sure that Texas would become stable both politically and economically. These were indispensable conditions for attracting new settlers, increasing land values, and securing the prosperity of the inhabitants.

The effects of Annexation, though not quite consummated, are already being developed. The M'Kim brought over between fifty and sixty passengers the last trip she made from New Orleans to Galveston, many of whom are visitors to see and examine this country. If they come at this time of the year, what may we expect in the fall? $?^{34}$

The editorial of March 4, 1846 summarized the public opinion, the pride and patriotic sentiments of Anglo-Americans in Texas. At the same time it marked the beginning of a new phase in the development of Texas identity.

The Ninth Anniversary of the National Independence of Texas has just passed by; but ere it dawned, Texas had ceased to exist as a Nation. When we turn to the pages of history, we find them teeming with lamentations over the fall of nations. The extinguishment of the independence of any nation, has hitherto been regarded as the worst calamity that could befall it, and it has generally affected only by bloodshed and carnage, and heralded by the greans? And lamentations of a humbled, spirit broken people; but the Independence of Texas passed away amid the joyous acclamations of her citizens, and the event is hailed as the dayspring of her future glory and greatness. We have seen within the year past one mighty nation yielding its assent to the admission of another nation into the bosom, and we have seen that Union effected with order, concord, and peace, and amid the almost universal rejoicings of the people of each country. When has the world witnessed a similar event? Ancient and modern history show no instance of a similar character. ${ }^{35}$

Texas became the 28th state in the United States of America. Its population more than quadrupled between 1836 and 1846, and according to the United States census of 1850, out of a total Texan population of 212.000, the number born outside the United States and Mexico was only 12.000. The great majority of the inhabitants were Anglo-Americans.

Although the Republic was unwilling to remain a beggar on the Union's doorstep after 1836, the eventual extension of American jurisdiction over Texas continued to be the desire of the great majority of the Anglo-Texans. Yet as Texas' independent status gained the appearance of permanence (and the recognition of the European powers), and as Texans exercised their unwanted rights of sovereignity, a virtually inevitable growth of nationalistic sentiment occured. Because of the relatively long period of self-rule, the intellectual ramifications of independence were of much greater consequence in Texas than in, for example, the earlier „Lone Star Republic” of West Florida (1810), or the later „Bear Flag

\footnotetext{
${ }^{32}$ Telegraph and Texas Register, April 16, 1845.

${ }^{33}$ Telegraph and Texas Register, April 23, April 30, 1845.

${ }^{34}$ Telegraph and Texas Register, August 13, 1845.

${ }^{35}$ Telegraph and Texas Register, March 4, 1846.
} 
Republic" of California (1846). Neither of these „republics” lasted longer than a month; the Texans sustained their Republic for almost a decade. ${ }^{36}$

${ }^{36}$ Clement EATON, A History of the Old South: The Emergence of a Reluctant Nation, 3rd ed., New York, Macmillan Publishing Co., Inc., 1975, 201-202; Robert V. HINE, The American West: An Interpretive History Boston: Little Brown and Company, 1973, 101-102 